\section{sciendo}

Journal of Central Banking Theory and Practice, 2021, 3, pp. 5-22

Received: 02 August 2020; accepted: 06 January 2021
UDK: 336.774.5(497.6)

DOI: 10.2478/jcbtp-2021-0021

* School of Economics and Business,

Sarajevo, Bosnia and Herzegovina

E-mail:

amilazunic.az@gmail.com

\title{
Non-Performing Loan \\ Determinants and Impact of \\ COVID-19: Case of Bosnia and Herzegovina
}

\author{
${ }^{* *}$ School of Economics and Business, \\ Sarajevo, Bosnia and Herzegovina \\ E-mail: \\ kemal.kozaric@efsa.unsa.ba \\ ${ }^{* * *}$ Central Bank of Bosnia and \\ Herzegovina, Sarajevo, \\ Bosnia and Herzegovina \\ E-mail: \\ zunic.emina@gmail.com
}

Abstract: The aim of this paper is to investigate the determinants of the movement of non-performing loans in the banking sector of Bosnia and Herzegovina, as well as the impact of the COVID-19 pandemic on them. For this purpose, secondary data from the banking sector of $\mathrm{BiH}$ were used, over which a multi-regression analysis was performed. The variables non-performing loans, GDP, loan loss provision, and dummy variable COVID-19 were used in the analysis. The results of the analysis showed a significant influence of all three mentioned variables. The existence of a significant positive link between non-performing loans and the state of the country's economy has been proven. In addition to the above, it has been proven that the variable COVID-19 has a delayed effect on NPLs, due to the current application of the moratorium on loans.

Keywords: NPLs, GDP, COVID-19, loan loss provision.

JEL Code: G00, G21.

\section{Introduction}

The growing turbulence of the financial market inevitably leads to the strengthening of banking risks. Against such backdrop, achieving a profitable business becomes a very difficult and challenging endeavour. Therefore, bank 
managers are tasked with creating an adequate plan and policy for controlling overall risks. Management is responsible for establishing balance and ensuring safe, stable, and profitable operations. There are various definitions of risk in the literature, one of which was given by Vaughan and Vaughan (1995) who define risk as: "A condition in which there is a possibility of a negative deviation from the desired outcome we expect or hope for. Therefore, we can say that in order for risk to exist in financial operations, it must: be possible, cause economic damage, be uncertain, and be accidental."

Since loans are the riskiest part of bank assets, their quality is one of the most important determinants of business stability and success. Although there is still no universally accepted definition of bad loans, the most commonly used definitions are those of the International Monetary Fund, the Basel Committee on Banking Supervision, and the Institute of International Finance. As defined by the Basel Committee on Risk Management, non-performing loans include all loans that are not collected within 90 days from the due date. If we take into account that one of the primary activities of all banks is the granting of loans, then the importance of banks' exposure to credit risk and its management becomes clear to us. Accordingly, several methods have been developed to manage this risk. They have best proven their effectiveness/inefficiency during financial crises. In this regard, there is more and more talk about bad loans and ways to solve them. Banks are getting closer to restructuring bad loans and clearing their balance sheets to create the preconditions for new credit growth.

The global spread of the coronavirus is a human tragedy that is taking place around the world, and Europe is considered the current epicentre. The coronavirus pandemic has caused an unprecedented shock to the economy and many businesses are experiencing difficulties in maintaining business. Not all of these businesses will survive nor will all households be able to repay the loans they took out before or during the pandemic. This means that an increase in non-performing loans is inevitable because a part of the loans will not be repaid in full. In order to minimize this increase, the European Central Bank (ECB) constantly emphasizes that banks should lend only to those clients who are likely to repay loans, even in difficult times. It also reminds banks of the need to closely monitor risks in order to identify non-performing loans early enough and start tackling the problem.

The choice of this topic was driven by the importance of bad loans that proved to be a major threat to the financial system. Namely, according to reports on the financial stability of central banks, the biggest threat to the financial stability of the banking sector is represented by non-performing loans. This paper analyses 
the impact of the Covid-19 pandemic on the problem of non-performing loans (NPLs), which includes the impact of loan loss provisions and real GDP growth rate.

The initial assumption is that these variables will have a significant impact on the level of non-performing loans. Therefore, this research should show whether and how these variables are related. In fact, with the help of an appropriate econometric methodology, it will be possible to find out whether these variables move together. Therefore, from the following review of the theoretical and empirical literature, it can be concluded that it is important to provide empirical evidence on the impact of these variables on non-performing loans.

\section{Literature review}

The banking sector is the dominant part of the financial system and as such represents a significant factor in the development of the overall economic system. In the past three decades, studies of the banking sector of transition economies have become more important due to banking reforms that included liberalization, privatization, and recapitalization of the banking sectors in the region (Grubišić, Kamenković, \& Kaličanin, 2020).

By analysing the available literature and works of other authors, a better insight into the research state of this field was gained. It was investigated what the authors of similar intentions wrote in the field of credit risk, non-performing loans, cost efficiency, and global banking. It was found that there are three directions in which the research of authors in this field moved, namely: analysis of microeconomic determinants, analysis of macroeconomic determinants, and a combination of micro- and macroeconomic determinants of non-performing loans. In addition to the above, the impact of COVID-19 on the movement of nonperforming loans, and the reaction of commercial banks to these events were presented.

One of the first papers in this area addresses the quality of loans and their impact on credit growth. Two measures of credit quality were investigated: the ratio of indebtedness to total loans and the ratio of non-performing loans and total loans. These measures are good indicators of the likelihood of bad credit (Clair, 1992). On the other hand, the authors investigated non-performing loans and efficiency in commercial banks. They tried to prove the connection between credit quality, cost efficiency, and capital. The results showed that non-performing loans lead to lower-cost efficiencies, that better cost efficiencies reduce non-performing loans, 
and that low-capitalized banks have greater problems with non-performing loans (Berger \& DeYoung, 1997). Other authors investigated the impact of risk and qualitative factors on efficacy. It was found that the level of financial capital has the greatest impact on the possibility of financing non-performing loans. The level of equity was used instead of the capital/asset ratio to monitor differences in risk preferences (Altunbas, Lin, Moyneux, \& Seth, 2000).

The following research is focused on the relationship between non-performing loans, short-term deposit rates, and the impact of interest rates on loans. It has been shown that the share of non-performing loans does not affect short-term deposit interest rates. But that it does affect interest rates on loans, and in a positive way. The interest margin is also positively related to interest rates on loans. The paper used the VAR (Vector Auto Regression) model for analysis on the example of 28 banks from Korea (Chang, 2006). Furthermore, the authors investigated the critical factors responsible for non-performing loans on the example of the Indian banking sector. Primary data collected from bank credit managers were used. They showed that external factors have a stronger influence than internal ones (Sanjeev, 2007).

In addition, the hypothesis of poor management has been proven, which refers to the fact that poor management leads to poorer cost efficiency, which results in higher rates of non-performing loans (Podpiera \& Weill, 2008). When analysing the problem of high levels of non-performing loans, Johnson (2009) showed that restructuring and clearing the balance sheets of large banks is the only sure way out of the situation in which the entire financial system finds itself.

Subsequent research focuses on the conflict between bank managers and owners over the topic of risk. It has been proven that risk-taking by banks correlates positively with the comparative strength of shareholders and the capital structure. Regulations such as capital requirements or deposit insurance affect managers and owners differently so the intensity of risk also depends on the strength of the influence of one or the other. It has been shown that the relationship between risk and regulation depends on the ownership structure of the bank (Leaven \& Levine, 2009).

Furthermore, the authors defined a model that has as its subject the cumulative effects of macroeconomic shocks over a three-year time horizon and their impact on non-performing loans. In this regard, the VAR model on the panel data was used to verify the set model (Espinoza \& Prasad, 2010). The effects of credit risk spillover between banks in one banking system, in this case the Mexican banking system, were further investigated. It has been proven that there is a spillover effect 
between small and large banks, as well as that it is two-way, which is surprising given that a one-way connection was expected (Herreriasa \& Moreno, 2011).

In addition, the impact of risk management on non-performing loans and profitability of Pakistan's banking sector was investigated. It was found that an adequate risk protection mechanism is not applied. It was concluded that non-performing loans are growing due to the lack of an adequate prevention and control methodology (Haneef et al., 2012). The following research focuses on non-performing loans in CESEE (Central Eastern Southeastern Europe) countries and their macroeconomic determinants.

The importance of conducting stress tests to support the monitoring of financial stability and interconnections in the financial system was further explored. This paper points out those short-term and long-term goals of stress tests that need to be addressed (Bookstaber et al., 2014). According to Cucinelli (2015), where banks avoid failure, NPLs impact negatively on a bank's cost structure and efficiency and their willingness to lend. Furthermore, according to Balgova, Nies, \& Plekhanov (2016), "as high levels of NPLs at some point arrest credit growth, the NPL ratio starts rising rapidly, while in "no NPL problem" countries it remains stable due to the healthy growth of credit and nominal GDP." In their research, Radivojević \& Jovović (2017) suggest that "the GDP has a crucial deterministic role for the NPLs ratio unveiling that the state of the economy of (selected) emerging countries is linked to bank asset quality." On the other hand, some authors have found out that prompt corrective action has a major impact on banking sector stability and decrease in the level of non-performing loans (Jiang, Kanas, \& Molyneux, 2018).

Unemployment, public debt, credit growth, lagged values of non-performing loans, the cost to income ratio and financial crises has positive effect on nonperforming loans (Bayar, 2019). In their paper, Kozarić \& Žunić Dželihodžić (2020) analyse the impact of macroeconomic conditions on non-performing loans and financial stability in Bosnia and Herzegovina's banking sector. The results have shown that improvement in macroeconomic conditions causes improvement in credit quality. Also, it was disclosed that better macroeconomic conditions ensure better conditions for the maintenance of the banking sector's financial stability.

During the COVID-19 pandemic NPLs identification has been prolonged by banks in an effort to delay recognition in the profit and loss statement, and to conceal the loss of capital. This behaviour may lead to continued financing of non-viable firms, the so-called zombie lending, and delay much-needed restructuring efforts at the firm level with negative consequences for economic growth. 
If forbearance measures are kept in place for too long, this issue is further exacerbated and more desirable measures, such as internal workouts or the transition to more market-based solutions are prevented (Kasinger et al., 2021). Effect of changing asset quality on risk weights is present for the internal ratings-based approach, in line with our expectations based on regulatory standards (Brož \& Pfeifer, 2021). The following paper reaches a conclusion that climate change can adversely affect balance sheets of financial institutions. Therefore, climate change is a source of financial risk and thus a part of the mandate of central banks and supervisors in preserving financial stability (Fabris, 2021). The findings of the following paper reveal the presence of significant positive long-run relationship between ROA, ROE, trade openness, and human capital, while government expenditures have negative impact on financial stability. Trade openness, human capital and government expenditures can keep the financial system stable as a whole (Zeqiraj, Iskenderoglu, \& Sohag, 2021).

Figure 1: NPLs movement

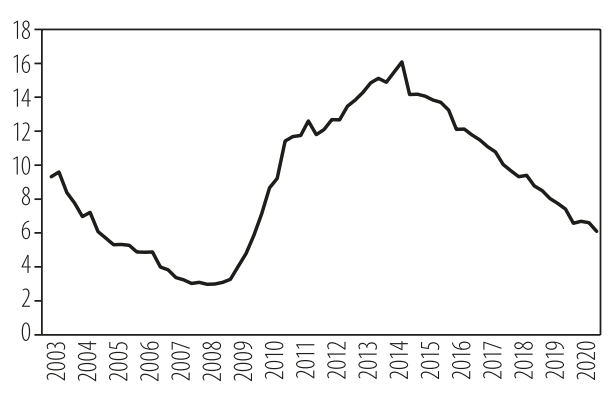

Source: Authors' interpretation
The figure 1 is a graphical representation of non-performing loans in the period from 2003 until the end of 2020. After the growth of NPLs recorded after the outbreak of the Global financial crisis, their decline followed from 2015 until the end of the analysed period. This movement of NPLs is one of the reasons for analysing the causes of the decline in their level s in the banking sector of Bosnia and Herzegovina.

\section{Hypothesis development}

A review of the literature was conducted to identify the hypotheses relevant to the achievement of the objectives of this research. Therefore, based on the early literature and variables of study, the following hypotheses are formulated:

H0: Non-performing loans level is determined by economic conditions and it is affected by crisis occurrence

Historically, the occurrence of banking crises has often been associated with a massive accumulation of non-performing loans which can account for a sizable share of total assets of insolvent banks and financial institutions, especially dur- 
ing episodes of systemic crises. Deterioration in banks' loan quality is one of the major causes of financial fragility. Past experience shows that a rapid build-up of bad loans plays a crucial role in banking crises (Demirgüç-Kunt \& Detragiache, 1998, and González-Hermosillo, 1999). In their research, Turan \& Koskija (2014) examine the continuous increase of NPLs in Albania resulting from problems caused by the economic crisis and the decrease of emigrant incomes. Namely, it has been shown that non-performing loans began to grow immediately after the outbreak of the financial crisis in 2008, but sharp growth occurred a year later when GDP in most CESEE countries experienced a contraction. In addition to these macroeconomic factors, the relatively high variability in non-performing loans indicates the existence of a negligible contribution of bank-specific factors (Klein, 2013).

\section{H1: Better macroeconomic conditions measured by GDP lead to lower NPL level}

Among the macroeconomic determinants, the results suggest that higher unemployment rate, exchange rate depreciation (against the euro), and higher inflation contribute to higher NPLs, while higher GDP growth results in lower NPLs (Klein, 2013). Also, Babouček \& Jančar found evidence of a positive correlation between NPLs, unemployment rates, and consumer price inflation, while GDP growth decreases the NPL rate.

H2: Higher riskiness of credit placements measured by credit loss provisions (reservations) leads to a higher level of NPLs

Keeton (1999) showed that rapid credit growth, which was associated with lower credit standards, contributed to higher loan losses in certain states in the US. The result in the research by Seyoum, Nigussie, \& Tesfay (2016) depicts that weak credit risk management and easily admitted borrowers cause occurrences of nonperforming loans.

\section{H3: COVID-19 crisis has postponed effect on NPL levels}

An increase in non-performing loans, deterioration of the quality of the loan portfolio, and possible extreme cases of bank runs are mentioned as the main negative consequences of COVID-19 for banks (Goodell, 2020). It can be expected that many of the company loans will become non-performing in the coming months. "What we have seen after the Global Financial Crisis and the Banking and the Sovereign Debt Crisis in the Eurozone was that the share of non-performing loans tends to be higher in countries with inefficient insolvency systems and tends to be lower in countries with more efficient insolvency systems" (Demary, 2021). 


\section{Research methodology}

In this scientific research we used formulation and presentation of research results, combinations of numerous general scientific methods such as analysis and synthesis methods, inductive and deductive methods, abstraction and concretization methods, specialization and generalization methods, and comparison methods. In the data collection, we used analysis of the content which is used to research scientific - theoretical knowledge, relevant literature, and modern business practice. For the analysis, the following variables were used: non-performing loans, loan loss provisions, GDP, dummy variable COVID-19. The analysis will be performed on quarterly data on these variables for the period 2012-2020. The sources of data were websites of the Banking Agencies and the Central Bank of Bosnia and Herzegovina. Namely, the goal was to determine the impact of the loan loss provisions, nominal GDP, as well as the impact of the COVID-19 pandemic on the level of non-performing loans. The data used in this study are presented quarterly. This time series is representative because it covers the prepandemic and pandemic periods. Thus, it was possible to detect the exact effect in moment of COVID-19 appearance. The statistical program SPSS (Statistical Package for the Social Sciences) was used for quantitative analysis.

Although we primarily planned to include the above variables in the model, preliminary analysis showed that some of them are not significant for modelling in the banking sector of Bosnia and Herzegovina, given their specifics. Therefore, the following variables are included in the model: nominal value of GDP, loan loss provisions, and impact of the COVID-19 pandemic.

Before carrying out the econometric analysis, descriptive data analysis had been provided as well as the verification of normality and symmetry distribution and the existence of multicollinearity problem. Since the model involves time series, the problem of autocorrelation may exist, but previous studies have shown that this approach is suitable for NPL time series analysis as long as the problem of autocorrelation is solved. Therefore, linear regression model in statistical literature is defined as follows (Somun-Kapetanović, 2008):

$$
y_{t}=\alpha+x^{\prime}{ }_{t} \beta+\varepsilon_{i},
$$

Where $y$ is the explained variable and, in this case, we will have model with dependent variable: non-performing loans. $\alpha$ is constant term and $\mathrm{x}$ is nxp matrix of independent variables, in this case: non-performing loans, loan loss provisions, nominal GDP, dummy variable COVID-19, and $\varepsilon$ is error term. 
Furthermore, the correlation between the variables was determined by applying the Pearson's Coefficient Correlation with the following rules:

- Very strong positive / negative correlation (+/- 0.81 to +/- 1$)$

- Strong positive / negative correlation (+/- 0.61 to $+/-0.80)$

- Moderate positive / negative correlation (+/- 0.41 to $+/-0.60)$

- Weak positive / negative correlation (+/- 0.21 to $+/-0.40)$

- No connection (+/- 0.00 to +/-0.20)

If the sign of the correlation coefficient was positive, then a positive correlation would have existed. If the sign of the correlation coefficient was negative, then a negative correlation would have existed (Sedgwick, 2012). Coefficient correlation can be measured as follows (Somun- Kapetanović, 2008):

$$
r=\frac{s s_{x y}}{\sqrt{S S x x \cdot S S y y}}
$$

where:

$$
\begin{aligned}
& \text { SSxy }=\sum\left(\mathrm{Xi}-\sum\left(\mathrm{x}_{\mathrm{i}}-\overline{\mathrm{x}}\right)\left(\mathrm{y}_{\mathrm{i}} 2 \overline{\mathrm{y}}\right)\right. \\
& \text { SSxx }=\sum_{i^{2}-1}^{n}\left(x_{i}-x\right)^{2} \\
& \text { SSyy }=\sum_{i=1}^{n}\left(y_{i}-\bar{y}\right)^{2}
\end{aligned}
$$

Multiple regression analysis will be applied to the collected data to obtain a specific model. The general form of the multiple regression model can be presented as follow:

$$
\mathrm{y}=\beta_{0}+\beta_{1} \cdot x_{1}+\beta_{2} \cdot x_{2}+\ldots+\beta_{k} \cdot x_{k}+\varepsilon
$$

where:

y - dependent variable,

$x_{1}, x_{2}, \ldots, x_{\mathrm{k}}$ - independent variable,

$\beta_{0}, \beta_{1}, \beta_{2}, \ldots, \beta_{\mathrm{k}}$ - estimated parameters,

$\varepsilon$ - random error (Bahovec \& Erjavec, 2009)

Based on these two statistical methods, a final judgment will be made on the impact of independent variables on the dependent one. Using the synthesis method, all individual conclusions will be combined into one global conclusion. The umbrella method that will unite everything that has been done so far is the method of generalization. 


\section{Research results}

At the beginning of the analysis, normality was tested to determine whether the data followed a normal distribution. After we determined the normality of the data by the Shapiro-Wilk test ( $\mathrm{p}=0.043$, confidence level 0.1 ), we can perform multiple regression.

Table 1: Tests of Normality

\begin{tabular}{ccccccc}
\hline & \multicolumn{3}{c}{ Kolmogorov-Smirnova } & \multicolumn{3}{c}{ Shapiro-Wilk } \\
& Statistic & Df & Sig. & Statistic & Df & Sig. \\
\hline NPL & .115 & 36 & $.200^{*}$ & .938 & 36 & .043 \\
\hline
\end{tabular}

Source: Authors` interpretation

Furthermore, the table below shows a description of the statistics for the observed variables. Table 2 shows the mean values and standard deviations as the average linear deviation around the mean values for each model variable.

Table 2: Descriptive Statistics

\begin{tabular}{lcc}
\hline & Mean & Std. Deviation \\
\hline NPL & 11.468 & 2.943 \\
\hline LOAN LOSS PROVISIONS & 4906.436 & 377.208 \\
\hline GDP & 7375251.416 & 599163.708 \\
\hline COV_19 & .111 & .319 \\
\hline
\end{tabular}

Source: Authors` interpretation

Namely, the purpose of the next part of the analysis reveals the potential correlation between dependent and independent variables. To determine the correlation between the variables of this model, we used the Pearson correlation coefficient. The following table shows the results of the correlation analysis.

Table 3: Correlation matrix

\begin{tabular}{|c|c|c|c|c|c|}
\hline & & NPL & LOAN LOSS PROVISIONS & GDP & COV_19 \\
\hline \multirow{4}{*}{$\begin{array}{l}\text { Pearson } \\
\text { Correlation }\end{array}$} & NPL & 1.000 & .032 & -.700 & -.606 \\
\hline & LOAN LOSS PROVISIONS & .032 & 1.000 & .339 & -.176 \\
\hline & GDP & -.700 & .339 & 1.000 & .232 \\
\hline & COV_19 & -.606 & -.176 & .232 & 1.000 \\
\hline \multirow{4}{*}{$\begin{array}{l}\text { Sig. } \\
\text { (1-tailed) }\end{array}$} & NPL & $\therefore$ & .042 & .000 & .000 \\
\hline & LOAN LOSS PROVISIONS & .042 & $\therefore$ & .022 & .0153 \\
\hline & GDP & .000 & .022 & $\therefore$ & .087 \\
\hline & COV_19 & .000 & .015 & .087 & . \\
\hline
\end{tabular}

Source: Authors` interpretation 
The results of the correlation analysis indicate a positive and statistically significant correlation between the level of non-performing loans and loan loss provisions. This link was expected as riskier placements required higher provisions for loan losses. Consequently, it is more likely that these loans will go into the category of non-performing. The variable GDP has a strong negative correlation with non-performing loans. This connection was expected since better economic conditions and stronger economic activity create conditions for better business, which is reflected in the creditworthiness of customers and, ultimately, in the level of non-performing loans. Although the growth of non-performing loans is expected during a crisis, in our case the variable that indicates the COVID-19 pandemic has a negative connection with non-performing loans. Thus, although there has been an evident slowdown in economic activity and the emergence of many problems in business cycles caused by COVID, this effect is still not visible on non-performing loans. Moreover, according to the current data, it is the opposite of what was expected. The reason for these results is the fact that the possibility of a moratorium was introduced, which "saved" many loans from being classified as low-quality. Therefore, a delayed effect is expected for this variable after the moratorium expires, which represents the potential for future research.

Table 4: Model Summary

\begin{tabular}{ccccc}
\hline Model & $\mathrm{R}$ & $\mathrm{R}$ Square & Std. Error of the Estimate & Durbin-Watson \\
\hline 1 & .852 & .726 & 1.612 & 1.130 \\
\hline
\end{tabular}

Source: Authors` interpretation

Furthermore, the Model summary and ANOVA are presented. In Table 4 we can see that the correlation coefficient $(\mathrm{R})$ is 0.852 , and on the other hand, the determination coefficient ( $\mathrm{R}$ Square) is 0.726 . The obtained results tell us that $72.6 \%$ of the change of the dependent variable (NPLs) can be explained by the change of independent variables (GDP, LOAN LOSS PROVISIONS, COVID-19). Furthermore, the Durbin-Watson coefficient is within the normal range (between 1.5 and 2.5) and amounts to 1.130, which means that we do not have a problem with autocorrelation.

Table 5: ANOVA

\begin{tabular}{|c|c|c|c|c|c|c|}
\hline & Model & Sum of Squares & Df & Mean Square & $\mathrm{F}$ & Sig. \\
\hline \multirow{3}{*}{1} & Regression & 219.958 & 3 & 73.319 & 28.228 & .000 \\
\hline & Residual & 83.117 & 32 & 2.597 & & \\
\hline & Total & 303.075 & 35 & & & \\
\hline
\end{tabular}

Source: Authors` interpretation 
As it can be seen, Table 5 - test shows us that the model is good and significant. Table 6 shows the coefficients of the independent variables and the VIF model. As we can see, all the variables of this model are statistically significant. Also, VIF amounts to $1.1224,1.254$, and 1.145 , which means that the model has no problem with multicollinearity.

Table 6: Coefficients (Statistical significance of variables)

\begin{tabular}{lcccc}
\hline \multicolumn{1}{l}{ Model } & T value & Sig. & \multicolumn{2}{c}{ Collinearity Statistics } \\
& & & Tolerance & VIF \\
\hline (Constant) & 6.853 & .000 & & \\
\hdashline LOAN LOSS PROVISIONS & 1.789 & .083 & .817 & 1.224 \\
\hline GDP & -6.411 & .000 & .797 & 1.254 \\
\hdashline COV_19 & -4.239 & .000 & .873 & 1.145 \\
\hline
\end{tabular}

Source: Author interpretation

The results of the performed regression analysis suggest the presence of the model with the analysed variables as follows:

$$
\text { NPLs }=28.96+0.01 \mathrm{LLP}-14.87 \mathrm{GDP}-3.88 \mathrm{COV}
$$

The obtained results tell us that if the loan loss provision increases by 1 unit, we expect that the level of non-performing loans will increase by $0.01 \%$ if other variables remain unchanged. Furthermore, if GDP increases by 1 unit, we expect that the level of non-performing loans will decrease by $14.87 \%$. On the other hand, the level of non-performing loans decreases with the advent of COVID-19. This unexpected connection is a consequence of the introduction of a moratorium on loans, which prevented the growth of the level of non-performing loans and led to the delay effect.

\section{Effects of Covid-19 on Western Balkan financial systems}

With the advent of the coronavirus, almost all world economies have seen a decline in economic activity, especially small and open economies such as countries of Western Balkans. Tourism-oriented countries such as Montenegro and Albania have seen a significant contraction with the onset of the corona crisis, as the corona crisis has hit the sector hardest. Countries such as BiH, Serbia, and Northern Macedonia, whose exports are part of the global supply chain to Western Europe, registered a slightly milder decline in economic activity. As the recovery is long and uncertain, and the crisis creates new opportunities, the joint 
action of the countries of the region is one of the ways to adequately respond to the crisis. One of the most important requirements for creating a common economic market is the coherence of investment policies and better promotion of the region as a whole to attract foreign direct investments, and creating a regional industrial area that will allow better integration into global supply chains for Western Europe.

The pandemic has led to a shock on both the supply and demand side, and the full effect, duration, and economic consequences are yet to be seen and cannot yet be fully predicted. Although the financial systems in countries in the region are mostly stable, sufficiently capitalized and liquid, the pandemic still poses a significant threat. Lower profitability, poorer asset quality, and lower credit growth will have negative effects on the economy and pose additional challenges to the financial stability of countries in the region. Therefore, regulators across the region have launched a series of activities to prevent a decline in economic activity and to maintain financial stability. The focus of central banks in this challenging time is to monitor liquidity and credit trends. In order to maintain financial stability throughout the region, regulatory easing measures have been introduced such as moratoriums on loan repayment, a change in the classification of credit risk, and a change in the terms after which a loan is considered uncollectible.

What poses additional risk to most countries in the region are the restrictions on monetary regimes in force in these countries, especially in $\mathrm{BiH}$, Kosovo, and Montenegro. In this regard, the central banks face additional challenges in managing liquidity of the financial systems and providing liquidity support itself. To create additional capital space for banks, regulators have introduced a number of measures such as the release of countercyclical capital reserves, the release of capital reserves to limit profit distribution, a temporary ban on the payment of bonuses to directors, and the like. When we talk about standard monetary policy measures in the region, the central banks in Albania, Northern Macedonia, and Serbia cut their reference interest rates. However, as a significant contraction in economic activity is expected as a result of measures to curb the spread of coronavirus, which is a consequence of both supply and demand shocks, the impact of monetary policy on this type of shock is limited. In this regard, the joint action of fiscal and monetary policies is becoming increasingly prominent in order to contribute to the stabilization of economic activities in these countries.

The coronavirus pandemic will have long-term consequences for general social and economic activity. In the current year, a record contraction was recorded, while positive expectations for the recovery of economic activity in the coming period are associated with more favourable development of the epidemiological 
situation and high reliability of the vaccine. The latest official projections of the European Commission and central banks in the region indicate a moderate recovery next year while reaching the pre-pandemic level is expected only at the end of 2022. In the coming years, very uneven economic growth is expected, i.e. a rapid recovery of industrial activities and stagnation or slower growth of service activities. Although there is a heterogeneous economic structure among the countries of the region, in all countries the service sector has recorded an increasingly important share in the overall structure of economic activity in recent years. Bearing in mind that the corona crisis will have the greatest impact on tourism, transport, and other service activities, the recovery will thus be slower in countries that are heavily dependent on these activities. The period of the great financial crisis in the EU was marked by a long recovery of economic activity, which returned to the pre-crisis level only after six years, among other things, followed by a strong impact of the public debt crisis on individual stagnation. At the same time, the recovery in the USA was achieved after three years, indicating that policy coherence, along with technological advances, largely determine the speed of recovery from crisis periods.

\section{Conclusion}

With their lending activity, banks are one of the most important participants in the modern financial market. Given that the placement of loans is the main activity of banks and the largest item in the assets of banks' balance sheets, it is very important that bank management successfully manages loans that banks grant to customers. The quality of approved loans has proven to be one of the main factors influencing the bank's profitability. And in recent decades bank managements have put a special focus on monitoring and managing the quality of loans and preventing the occurrence of non-performing loans.

Although countries define the term non-performing loan differently, its definition in $\mathrm{BiH}$ does not differ significantly from the definition used in developed countries. In the period following the Global financial crisis, non-performing loans were also a problem in the $\mathrm{BiH}$ banking sector.

Due to the Global financial crisis, there was a decrease in economic activities, and thus a decrease in the purchasing power of individuals and legal entities, so banks faced an increase in the number of NPLs. However, with the emergence of the coronavirus pandemic, credit risk is expected to increase, and according to some research, the banking sector in our region could face one of the most difficult years after the global financial crisis of 2007. Due to the outbreak of the 
coronavirus pandemic, the Banking Agency in Bosnia and Herzegovina passed decisions on temporary measures for recovery fromnegative economic consequences. The results of the measures remain to be seen.

The analysis of the collected data from the banking sector of Bosnia and Herzegovina identified the relations between the assumed determinants and non-performing loans. Thus, it was determined that the improvement of non-performing loans is largely due to the improvement of economic conditions in the country. On the other hand, their growth is related to the growth of loan loss provisions as one of the indicators of quality of the loan portfolio. The impact of the COVID-19 pandemic on NPLs in the banking sector of Bosnia and Herzegovina is not yet adequately noticeable given the introduced moratorium on loans. Namely, these moratoriums have largely prevented loans from moving into the category of nonperforming loans, and the real effect of COVID-19 on this variable is expected only after the expiration of the moratorium period. Therefore, this may be interesting for further research, as well as some other macroeconomic determinants that could have implications for NPLs.

Although the recovery is uncertain and long, it needs to be used to create a regional economic market as a path to stronger and more sustainable growth for all Western Balkan countries. Thus, as is the case with the world's leading central banks, the central banks in the region are increasingly turning to non-standard monetary policy measures to adequately respond to the challenges posed by the COVID-19 pandemic. In this regard, the joint action of fiscal and monetary policy is becoming increasingly prominent in order to contribute to the stabilization of economic activities in these countries. A rapid recovery of activities in the EU, as the most important foreign trade partner, is crucial for the countries in the region as that will have a positive impact on exports, investments, and personal consumption. 


\section{References}

1. Altunbas, J., Lin, M. H., Moyneux, P., \& Seth, R. (2000). Efficiency and risk in Japanese banking. Journal of banking and finance.

2. Babouček, I.; Jančar, M. Effects of Macroeconomic Shocks to the Quality of the Aggregate Loan Portfolio; Working Paper Series, No. 1; Czech National Bank: Praha, Czech, 2005.

3. Bahovec, V. \& Erjavec, N. (2009). Uvod u ekonometrijsku analizu. Element, Zagreb.

4. Balgova, M., Nies, M., \& Plekhanov, A. (2016). The Economic Impact of Reducing Non-Performing Loans. SSRN Electronic Journal. doi:10.2139/ ssrn.3119677

5. Bayar, Y. (2019). Macroeconomic, Institutional and Bank-Specific Determinants of Non-Performing Loans in Emerging Market Economies: A Dynamic Panel Regression Analysis. Journal of Central Banking Theory and Practice, 8(3):95-110

6. Berger, A. N., \& DeYoung, R. (1997). Problem loans and cost efficiency in commercial banks. Journal of banking and finance.

7. Bookstaber, R., Cetina, J., Feldberg, G., Flood, M., \& Glasserman, P. (2014). Stress tests to promote financial stability: Assessing progress and looking to the future. Journal of Risk Management in Financial Institutions, 16-25.

8. Brož, V. \& Pfeifer, L., $\left.{ }^{\star} 2021\right)$, Are risk weights of banks in the Czech Republic procyclical? Evidence from wavelet analysis, Journal of Central Banking Theory and Practice, 113-139

9. Chang, Y. T. (2006). Role of NPLs and capital adequacy in banking structure and competition. IMF Working paper.

10. Clair, R. T. (1992). Loan growth and loan quality: some preliminary evidence from Texas banks. Economic Review, 9-22.

11. Cucinelli, D. (2015) "The impact of non-performing loans on bank lending behavior: Evidence from the Italian banking sector”, Eurasian Journal of Business and Economics, 8: 59-71.

12. Demary, M. (2021). Will COVID-19 cause insolvencies, zombification or debt deleveraging? (No. 3/2021). IW-Kurzbericht.

13. Demirgüç-Kunt A. \& E. Detragiache .1998. The Determinants of Banking Crises: Evidence from Developed and Developing Countries. IMF Staff papers, Vol. 45, No. 1.

14. Espinoza, R., \& Prasad, A. (2010). Nonperforming loans in the GCC banking system and their macroeconomic effects. IMF working paper.

15. Fabris, N. (2021). Financial Stability and Climate Change. Journal of Central Banking Theory and Practice, 27-43. 
16. Goodell, J. (2020). COVID-19 and finance: Agendas for future research. Finance Research Letters, vol 35.

17. González-Hermosillo, B. 1999. Determinants of ex=-ante banking system distress: A macro empirical exploration of some recent episodes. IMF Working Paper, 33.

18. Grubišić, Z., Kamenković, S., \& Kaličanin, T. (2021). Comparative Analysis of the Banking Sector Competitiveness in Serbia and Montenegro. Journal of Central Banking Theory and Practice, 1, 75-91.

19. Haneef, S. (2012). Impact of risk management on non-performing loans and profitability of banking sector of Pakistan. International Journal of Business and Social Science.

20. Herreriasa, R., \& Moreno, J. O. (2011). Spillovers and long-run diffusion of non-performing loans risk. Midwest finance association.

21. Jiang, C., Kanas, A. and Molyneux, P., 2018. Public policy and financial stability: The impact of PCA and TARP on U.S. bank non-performing loans, International Journal of Finance \& Economics, 23(4): 376-392

22. Johnson, S. (2009). The Quiet Coup. The Atlantic Online, 1-11.

23. Kasinger, J., Krahnen, J. P., Ongena, S., Pelizzon, L., Schmeling, M., \& Wahrenburg, M. (2021). Non-performing loans-new risks and policies? NPL resolution after COVID-19: Main differences to previous crises (No. 84). SAFE White Paper.

24. Keeton, W. (1999). Does faster loan growth lead to higher loan losses? Economic Review, vol 84, pp 57-75

25. Klein, N. (2013). Non-performing loans in CESEE: Determinants and impact on macroeconomic performances. IMF Working paper.

26. Kozarić, K., Žunić Dželihodžić, E. (2020). Effects of Macroeconomic Environment on Non-Performing Loans and Financial Stability: Case of Bosnia and Herzegovina. Journal of Central Banking Theory and Practice, pp. 5-17.

27. Leaven, L., \& Levine, R. (2009). Bank governance, regulation and risk taking. Journal of financial economic.

28. Podpiera, J., \& Weill, L. (2008). Bad luck or bad management? Emerging banking market experience. Journal of financial stability.

29. Radivojević, N., \& Jovović, J. (2017). "Examining of Determinants of Non-Performing Loans," Prague Economic Papers, Prague University of Economics and Business, vol. 2017(3), pages 300-316.

30. Sedgwick, P. (2012). Pearson's correlation coefficient. BMJ, 345(jul04 1), e4483-e4483.

31. Seyoum, A., Nigussie, H., \& Tesfay, T. (2016). Factors affecting nonperforming loans: case study on development bank of Ethiopia central region. 
32. Somun - Kapetanović, R., 2008. Statistika u ekonomiji i menadžmentu. Sarajevo: School of economics and business Sarajevo, pp.65

33. Turan, G., Koskija, A. 2014. Nonperforming Loans in Albania. Academic Journal of Interdisciplinary Studies. MCSER Publishing, 3(3), 491-500.

34. Vaughan, E., \& Vaughan, T. (1995). Osnovi osiguranja - Upravljanje rizicma. Zagreb: Mate.

35. Zeqiraj, V., Iskenderoglu, O., \& Sohag, K. (2021). Dynamic Impact of Banking Performance on Financial Stability: Fresh Evidence from Southeastern Europe, Journal of Central Banking Theory and Practice, 165181. 